\title{
A Clinical Study of Acute Epiglottitis: Retrospective Review of 315 Patients in Korea
}

\author{
Byeong Joon Kim, Byung Gil Choi, Hyo Geun Choi, Jun Young Lee, and Bum Jung Park \\ Department of Otorhinolaryngology-Head and Neck Surgery, Hallym University Sacred Heart Hospital, \\ Hallym University College of Medicine, Anyang, Korea
}

급성 후두개염의 임상적 고찰: 후향적 차트 리뷰 315예

김병준 · 최병길 · 최효근 · 이준영 · 박범정

한림대학교 의과대학 한림대학교 성심병원 이비인후-두경부외과학교실

\author{
Received June 22, 2018 \\ Revised October 18, 2018 \\ Accepted November 5, 2018 \\ Address for correspondence \\ Bum Jung Park, MD \\ Department of Otorhinolaryngology- \\ Head and Neck Surgery, \\ Hallym University \\ Sacred Heart Hospital, \\ Hallym University \\ College of Medicine, \\ 22 Gwanpyeong-ro 170beon-gil, \\ Dongan-gu, Anyang 14068, Korea \\ Tel $+82-31-380-3842$ \\ Fax $+82-31-386-3860$ \\ E-mail pbj426@hallym.or.kr
}

Background and Objectives Acute epiglottitis is a life-threatening condition that can result in airway obstruction. The present study reports clinical features, management and patient outcomes in an acute epiglottitis.

Subjects and Method Included in our retrospective study were 315 patients who were admitted with the diagnosis of acute epiglottitis between January 2006 and July to the department Otolaryngology-Head and Neck surgery, Hallym University Sacred Heart Hospital 2018. The diagnosis of acute epiglottitis was established by confirmation of inflamed epiglottis using laryngoscope or computed tomography.

Results Among 315 patients, 89 cases $(28 \%)$ and 83 cases $(26 \%)$ were found in the fifth and fourth decades, respectively. The mean age of patients was $45.0 \pm 13.94$ years. The male to female ratio was $1.33: 1$. A total of 75 patients $(23.8 \%)$ had co-morbidities, with hypertension $(13.6 \%)$ being the most common. Fever was relatively uncommon, whereas most patients complained of sore throat. Ceftriaxone was the most common empirical antibiotic regimen prescribed and the use of steroids did not affect the length of hospital stay. Nine patients required airway intervention, including eight who underwent endotracheal intubation and one emergency tracheostomy. In patients who need airway intervention, systolic blood pressure, body temperature, respiratory rate, heart rate, white blood cells and the proportion of dyspnea were significantly higher in comparison to the patients without airway intervention.

Conclusion Although acute epiglottitis often has nonspecific symptoms, it may lead to sudden dyspnea and unstable vital signs, so an in-depth understanding of this disease is needed. Korean J Otorhinolaryngol-Head Neck Surg 2019;62(4):233-7

Key Words Airway managment · Antibiotics · Epiglottitis.

\section{서 론}

급성 후두개염은 성문상부의 염증성 질환으로 인후통, 연 하곤란, 호흡곤란, 목소리 변화 등의 임상적 증상을 특징으로

This is an Open Access article distributed under the terms of the Creative Commons Attribution Non-Commercial License (https://creativecommons.org/licenses/by-nc/4.0) which permits unrestricted non-commercial use, distribution, and reproduction in any medium, provided the original work is properly cited.
하며 특히 앙와위(supine position)에서 심해지는 경향이 있 다. ${ }^{1)}$ 이전 연구 결과들에 따르면 열은 비교적 흔치 않다고 보 고되고 있다.2) 일부에서는 기도의 폐쇄를 통해 급격한 호흡 곤란을 일으켜 치명적일 수 있으며 특히 성인에 비해 소아에 서 급격히 진행하는 편이다. ${ }^{3)}$ 3세 이상의 소아에서 호발 하 나 haemophilus influenzae type B에 대한 예방접종이 보편 화 된 이후에는 소아에서는 발생빈도가 감소하고 있다. 성인 
에서는 빈도가 증가한다는 보고가 있으나 연구결과는 드물 다. ${ }^{4.5)} 2006$ 년 미국의 통계에 따르면 소아 100000 명 당 0.5 예, 성인 100000 명당 1.9 예의 유병률이 보고되고 있으며, 성인의 경우 남성 및 고령에서 호발 하는 것으로 알려져 있다. ${ }^{1,677}$ 급 성 후두개염은 갑작스런 기도폐쇄를 일으킬 수 있는 만큼, 비 특이적인 증상인 인후통과 연하곤란 등을 호소하는 환자에 서 급성 후두개염의 가능성을 염두에 두는 것이 중요하다. 이를 위해 급성 후두개염에 대한 철저한 이해가 필요하므로 저자들은 지난 13년간 본원에 입원하였던, 급성 후두개염 환 자 315예에 대하여 임상적 특징과 검사소견, 치료성적 등에 대해 후향적으로 분석하여 결과를 보고하고자 한다. 또한 기 도 중재 시술(airway intervention)이 필요하였던 환자군과 필요하지 않았던 환자군 간의 임상적 특징과 검사소견, 치료 결과 등의 차이를 비교 및 검증함으로써, 기도중재가 필요한 중증 후두개염에 대한 이해를 높이고자 한다.

\section{대상 및 방법}

2006년 1월부터 2018년 7월까지 본원 이비인후과에서 급 성 후두개염으로 진단 하에 입원하여 항생제 치료를 받은 환 자를 대상으로 후향적 분석을 진행하였다. 급성 후두개염 환 자 315예에 대하여 이번 연구를 위해 고안된 양식으로 후향 적으로 데이터를 수집 하였으며, 양식에는 나이, 성별, 입원기 간, 기저질환, 증상, 항생제 종류, 스테로이드 사용여부, 기도 중재 여부, 내원 당시 혈압, 심박수, 호흡횟수, 체온, 조영 증강 경부 전산화단층촬영 여부, 검사소견이 포함되었으며, 검사소 견으로는 C-reactive protein(CRP)와 백혈구 수를 측정하였 다. 진단은 후두경을 이용하여 후두개의 발적 및 부종 혹은 조영증강 경부 전산화단층촬영(neck contrast enhanced computed tomography, Neck CT)통해 결정하였다. 후두경 검사 및 Neck CT 상 후두개 자체의 부종보다는 부인두 공간(parapharyngeal space), 후인두 공간(retropharyngeal space) 등 의 부종이 심하여 심경부 감염(deep neck infection)으로 진단 하는 것이 보다 적절하다고 판단되는 환자들은 제외하였다. 일원분산분석(IBM SPSS 23 ver., IBM Corp., Armonk, NY, USA)을 이용하여 통계적 분석을 시행하였으며, 기도 중재가 필요하였던 중증 후두개염과, 필요하지 않았던 비중증 후두 개염 두 그룹으로 나누어, 각 그룹에 따른 성비, 스테로이드 사 용 여부, Neck CT 촬영 여부, 기저질환, 증상, 농양(abscess) 여부를 카이제곱 검정 혹은 Fisher의 정확한 검정으로 분석 하였다. 또한 두 그룹에 따른 나이, 입원기간, $\mathrm{CRP}$, 백혈구 수, 혈압, 심박수, 호흡횟수, 체온에 대해 t-test 분석을 시행하였 다. 스테로이드 사용 여부에 따른 입원기간 차이를 t-test를 이
용하여 분석하였다. 이번 연구는 본 기관의 임상연구심의위원 회(IRB)의 연구승인(승인번호: 2018-04-021-001)을 받았다.

\section{결 과}

\section{역 학}

환자의 평균 연령은 $45.0( \pm 13.944)$ 세로 연령 분포는 50 대 와 40대가 각각 315예 중 89예, 83예로 가장 많았고, 10대는 14예, 10세 미만은 1예였다. 성별은 남자 180예, 여자 135예로, 남녀 비율은 $1.33: 1$ 로 남자가 많았다. 환자의 나이에 다른 성 별 분포는 Fig. 1과 같았다. 평균 입원기간은 4.94( \pm 2.610$)$ 일 이었으며, 가장 입원기간이 짧았던 환자는 1 일, 가장 길었던 환자는 14 일이었다. 월별 환자수는 Fig. 2와 같았으며 7월과 10 월이 41예, 36예로 가장 많았다. 기저질환이 있는 환자는 315 예 중 75예(23.8\%)였고, 빈발 기저질환은 고혈압 43예(13.6\%), 당뇨 20예(6.3\%), 갑상선 질환 7예(2.2\%)순이었다.

\section{임상 증상 및 검사 소견}

환자들이 호소하는 주요 증상은(복수 응답 가능) 인후통 (sore throat)이 299예(94.9\%)로 가장 많았고, 호흡곤란 66예

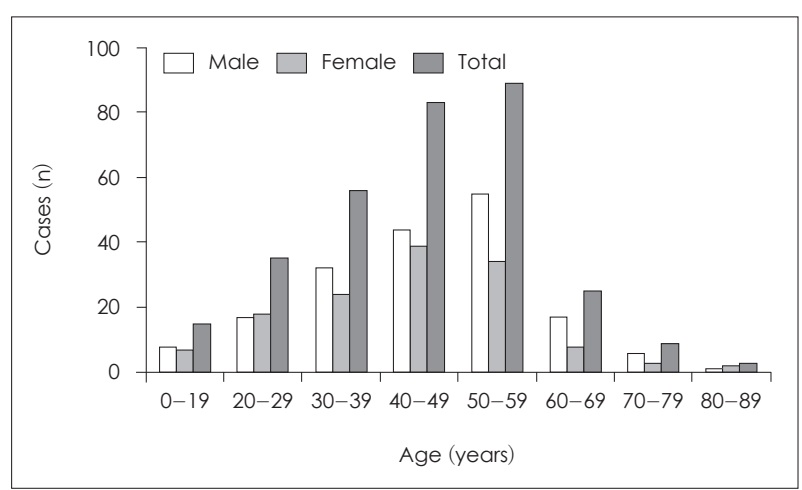

Fig. 1. Distribution of acute epiglottitis cases over the 13-years study period, by age $\&$ sex.

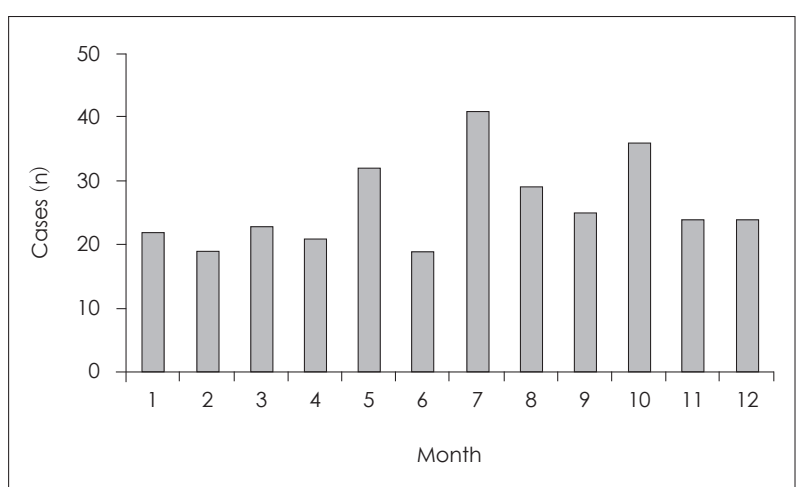

Fig. 2. Incidence of acute epiglottitis cases over the 13-years study period, by months. 
(21.0\%), 연하곤란 63예(20.0\%), 목소리 변화 32예(10.2\%) 순 이었다. 열은 16 예(5.1\%)로 비교적 드물었다. 내원 당시의 white blood cell는 모든 환자에서 측정되었고 평균 13.83× $10^{3}\left( \pm 5.006 \times 10^{3}\right)$ 개 $/ \mathrm{mm}^{3}$ 로 측정되었다. $\mathrm{CRP}$ 는 측정되지 않 은 51 명과 결과상 1 미만으로 보고된 12 명과 200 초과로 보고 된 4명은 절대값을 알 수 없어, 평균값 측정에서 제외하였다. 앞 서 언급한 67 명을 제외한 총 248 명의 평균 $\mathrm{CRP}$ 는 51.03 ( \pm $57.14) \mathrm{mg} / \mathrm{dL}$ 였다. 환자들의 내원 당시 측정된 첫 번째 평균 혈압은 수축기 $124.39( \pm 18.61) \mathrm{mm} \mathrm{Hg}$, 이완기 79.69( \pm 42.26$)$ $\mathrm{mm} \mathrm{Hg}$ 였으며, 평균 심박 수는 84.66( \pm 14.19$)$ 회/분이었다. 평 균 호흡횟수는 20.41( \pm 2.08$)$ 회/분이었으며, 평균 체온은 $37.13( \pm 0.79){ }^{\circ} \mathrm{C}$ 였다(Table 1).

\section{약물 치료}

315예의 모든 환자들이 정맥으로 경험적 항생제 치료를 받았으며, 다수에서 복수의 항생제 치료를 받았다. 빈도를 보 면, ceftriaxone이 176예로 가장 많았으며, 이어서 ampicillin with sulbactam 128예, metronidazole 21예, cefotiam 9예, netilmicin 8예, clindamycin 6예, amoxicillin with clavulanate 6예 순이었다. 스테로이드는 총 315명 중에 79.7\%인 251명에서 사용하였으며, 스테로이드[intravenous dexamethasone(덱사에스주, dexamethasone disodium phosphate 5 $\mathrm{mg}(5 \mathrm{mg} / \mathrm{mL})$, 일성신약, 서울, 대한민국)]를 사용한 환자에 서의 평균 입원기간은 $4.73( \pm 1.87)$, 사용하지 않은 환자에서의 평균 입원기간은 $4.60( \pm 1.30)$ 로 통계적으로 유의한 차이는 없었다 $(p=0.687)$.

\section{기도 중재 시술(Airway intervention)}

315 명의 환자 중 대부분이 보존적 치료만 시행 받았으며, 급격한 호흡 곤란 등으로 기도 중재가 필요 하였던 환자는 총 9명 이었다. 사망 환자는 없었다. 8 명의 환자에서 기관 삽관을 시행 하였으며, 그 중 2 명이 기관 삽관 기관이 길어져 기관절 개술을 시행하였다. 기관 삽관에 실패하여 응급으로 기관 절 개술을 시행한 환자는 1 명이었다. 기도 중재가 필요하였던 그 룹과 필요하지 않은 그룹 간의 임상 증상, 혈액검사 결과, 생 체 징후의 차이는 Table 1 과 같았다. 기도 중재가 필요하였던 그룹에서, 기도 중재를 시행하지 않은 그룹 보다 남자의 비율 이 유의하게 높았고 $(p=0.000)$, 나이는 유의한 차이가 없었다. 혈액 검사에서는 기도 중재가 필요 하였던 그룹에서 백혈구 수가 유의하게 높은 것으로 나타났다. 두 그룹에서 내원 당시 의 주소(chief complaint)를 비교해 보았을 때, 인후통, 연하 곤란, 목소리 변화, 열에는 차이가 없었으나, 호흡곤란을 호 소한 환자의 비율은 기도 중재를 시행한 그룹이, 시행하지 않
Table 1. Clinical characteristics of acute epiglottitis in with airway intervention group and non-airway intervention group

\begin{tabular}{|c|c|c|c|}
\hline \multirow{2}{*}{ Characteristic } & \multicolumn{2}{|c|}{ Airway intervention } & \multirow{2}{*}{$p$-value } \\
\hline & No & Yes & \\
\hline Patient & 306 & 9 & \\
\hline Sex & & & $0.000^{*}$ \\
\hline Male & 171 & 9 & \\
\hline Female & 135 & 0 & \\
\hline Sore throat & 291 & 8 & 0.360 \\
\hline Dyspnea & 59 & 7 & $0.000^{*}$ \\
\hline Dysphagia & 63 & 0 & 0.213 \\
\hline Hoarseness & 32 & 0 & 0.606 \\
\hline Fever & 15 & 1 & 0.378 \\
\hline Duration of admission & 4.72 & 9.88 & $0.000^{*}$ \\
\hline WBC $\left(\times 10^{3}\right.$ cells $\left./ \mathrm{mm}^{3}\right)$ & 13.72 & 17.67 & $0.020^{*}$ \\
\hline CRP (mg/DL) & 50.76 & 62.50 & 0.620 \\
\hline Systolic BP & 123.40 & 157.78 & $0.000^{*}$ \\
\hline Diastolic BP & 79.35 & 91.11 & 0.412 \\
\hline Respiratory rate (/min) & 20.37 & 25.56 & $0.000^{*}$ \\
\hline Heart rate (/min) & 83.95 & 108.89 & $0.000 *$ \\
\hline Body temperature $\left({ }^{\circ} \mathrm{C}\right)$ & 37.11 & 37.99 & $0.001 *$ \\
\hline
\end{tabular}

은 그룹보다 유의하게 높은 것으로 나타났다 $(p=0.000)$. 생체 징후 별로 나누어 봤을 때, 이완기 혈압을 제외한 모든 생체 징후(호흡횟수, 심박수, 체온)에서 유의한 차이가 있었다. 입 원기간은 기도 중재를 시행한 경우, 평균 재원기간 9.88일로 기도 중재를 시행하지 않은 그룹의 재원기간인 4.72일에 비해 서 유의하게 긴 것으로 나타났다. 그 외에 고혈압, 당뇨 등의 기저질환 유무와 스테로이드 사용 여부, Neck CT 촬영 여부, $\mathrm{CT}$ 상 농양의 유무는 유의한 차이가 없었다.

\section{고 찰}

급성 후두개염은 연하곤란, 인후통, 호흡곤란 등을 특징으 로 하며 급격한 상기도 폐쇄를 일으켜 치명적 일 수 있는 질 환이다. 이전에는 소아에서 호발하던 질환이었으나, Haemophilus influenzae type B에 대한 예방접종이 보편화 되 면서, 소아에서는 그 발생 빈도가 급격히 줄어들었다. 성인에 서의 유병률은 빈도가 증가하고 있다는 연구와, 안정적으로 유지되고 있다는 연구가 대립하고 있다. $\left.{ }^{48}\right)$ 본 연구에서는 10 년간 10 세 미만의 환자는 단 한 명뿐이었고, $\mathrm{Chu}$ 등 ${ }^{4}$ 의 연구 결과와 같이, 남녀 비율은 1.58:1로 남자에게서 호발 하였다. 월 별 발생률에서는 Kass 등의 의 연구와 같이 여름(7월)에 발 생한 환자들이 가장 많았다. 임상증상으로는 인후통 및 연 하곤란이 가장 흔하며 성인의 경우 대개 2 3일 간의 인후통 
으로 시작하여 연하곤란과 호흡곤란으로 진행한다. ${ }^{1)}$ 본 연구 도 국내외의 연구결과와 같이 인후통이 가장 많았고 호흡곤 란, 연하곤란, 목소리 변화 순이었다. 반면 발열은 비교적 드 물었다. 성인과 달리, 소아에서는 갑작스런 발열과 천명음, 호 흡곤란이 흔한 것으로 알려져 있는데, 이는 소아의 성문 주 변부 조직이 연하여 쉽게 부종을 일으킬 수 있으며, 기도의 직경이 좁기 때문에 상대적으로 쉽게 기도폐쇄를 유발 할 수 있기 때문이다. ${ }^{10)}$ 평균 입원 기간은 4.94일이었고, 전반적으 로 고령 환자에서 재원기간이 긴 경향이 있었으나, 이는 연령 에 따른 기저질환의 빈도 증가 및 취약한 전신 컨디션 등을 고려하여야 할 것이다. 급성 후두개염의 진단은 환자의 병력 과 신체검사, 영상검사, 후두경 검사 등을 통해 이뤄진다. 대 개 후두경을 통해 직접 후두개의 발적과 부종을 확인함으로 써 진단 할 수 있지만, 급격한 호흡곤란으로 후두경 검사를 시행 할 수 없는 경우, 조영증강 경부 전산화단층촬영으로 후 두개염을 확인 할 수 있다. ${ }^{11)}$ 경부 연조직 방사선 검사를 통한 'Thumb sign'의 확인도, 급성 후두개염의 진단에 도움을 줄 수 있다. ${ }^{12)}$ 급성 후두개염의 치료 원칙에서 가장 중요한 것은 기도를 확보 하는 것으로, 대부분의 경우 항생제 및 스테로 이드 등 보존적 치료만으로 회복이 가능하다. ${ }^{1,4)}$ 본 연구의 경우 급격한 호흡곤란 및 불안한 생체징후로 인해 기관 내 삽관, 기관절개술 등의 기도 중재 시술이 필요하였던 환자는 315 명 중에 9명뿐이었다. 항생제는 1차 약제로서 3세대 cephalosporin 계열인 ceftriaxone이 권고 되고 있으며, 2차 약제 로는 ampicillin with sulbactam, cefotaxime, piperacillin with tazobactam 등이 사용되고 있다. ${ }^{13,14)}$ 스테로이드는 기 도의 염증 및 종창 완화 등을 목적으로 사용하며, 입원기간, 기관 삽관 기간, 중환자실 입원기간 등을 단축 시킨다는 연 구들이 있으나, 여러 연구들을 후향적으로 분석하였을 때, 아직까지 그 효용성이 입증된 것은 아니다. ${ }^{15)}$ 본 연구에서는 스테로이드를 사용한 환자 군의 경우 입원기간 4.73일로 스 테로이드를 사용하지 않은 환자 군의 입원기간인 4.61일에 비해 길었으나, 유의한 차이는 아니었다. 하지만 임상적으로 심한 증상을 호소하거나, 후두경 상 종창이 심한 경우에 스 테로이드 사용을 선호하는 경향이 있으므로, 선택 편향 (bias)이 작용하였음을 고려하여야 한다. 기도 중재 시술을 받은 환자들의 비율은 낮게 나타났는데(Frantz 등 ${ }^{16)} 15 \%$, Hébert 등 ${ }^{17)} 20 \%$, MayoSmith 등 ${ }^{18)} 21 \%$ ), 이는 과거에 비해 초기에 내원하는 경우가 많아진 점과 광범위 항생제의 발전 에 기인한 것으로 생각된다. 또한 본 연구에서 기도 중재가 필요한 급성 후두개염 환자들에게 응급 기관절개술 보다는 기관 삽관을 시행한 비율이 월등히 높은데, 이는 본원의 경 우 상급 종합 병원으로서, 기관 삽관에 능한 응급의학과 및
마취과 의료진이 충분하고, 실패 시 즉시 응급 기관 절개술 을 시행할 수 있도록 이비인후과 의료진이 대기한 상태에서 기관 삽관을 시행하였기 때문이다. 본 연구에서는 기도 중재 가 필요하였던 9명의 환자들을 통해 보존적 치료만으로는 충분치 않은 급성 후두개염 환자들의 특징 및 위험인자를 분석하고자 하였다. 앞선 문헌들에 따르면, 호흡곤란, 농양의 여부, 천명음의 여부, 당뇨 유무, 증상의 빠른 발생 등이 기도 중재의 위험인자로 알려져 있다. ${ }^{17,19)}$ 본 연구에서는, 내원 당시 의 주요 증상으로 호흡 곤란을 호소하는 비율이 유의하게 높 았으며, 이완기 혈압을 제외한 모든 생체징후(수축기 혈압, 호 흡 횟수, 심박수, 체온) 또한 보존적 치료만으로 회복이 가능 했던 그룹에 비해 유의하게 높은 것으로 나타났다. 농양의 여 부, 당뇨의 유무 등은 두 그룹간의 유의한 차이가 없었다. 본 연구의 한계로는 첫째, 후향적 차트 리뷰로 진행이 되었다는 점; 둘째, 연구 기간 동안 소아 환자 비율이 현저히 낮아, 성인 및 소아 후두개염을 비교 할 수 없었다는 점; 셋째, 기도 중재 시술이 필요한 그룹과 필요하지 않은 그룹의 비교에서, 두 그 룹간의 환자 수 차이가 크기 때문에, 통계적 유의성이 다소 떨어질 수 있다는 점이며 이러한 부분을 보완하기 위해 추후 의 대규모 연구가 필요할 것으로 사료된다. 급성 후두개염은 인후통, 연하곤란과 같은 비특이적인 증상으로 시작하여 급 격한 호흡곤란 및 불안정한 생체징후를 일으킬 수 있으므로, 이 질환에 대해 충분히 숙지하고 기도의 확보가 지연되는 일 이 없도록 해야 할 것이다. 따라서 급성 후두개염 환자가 호흡 곤란을 호소하거나 빈맥( $\mathrm{HR}>100)$, 빈호흡(RR>20) 등의 불 안정한 생체 징후를 보인다면 기관 삽관 혹은 기관 절개술 등으로 보다 적극적인 기도 확보를 고려 하여야 할 것이다.

\section{ORCID}

Bum Jung Park https://orcid.org/0000-0001-6074-6339

\section{REFERENCES}

1) You KM, Kwon WY, Suh GJ, Kim KS, Kim JS, Park MJ. Clinical features of acute epiglottitis in adults in the emergency department. J Korean Soc Emerg Med 2016;27(1):126-33.

2) Marx JA, Hockberger RS, Walls RM. Rosen's emergency medicine: concepts and clinical practice. 8th ed. Philadelphia: Elsevier-Saunder; 2014. p. 969

3) Shah RK, Stocks C. Epiglottitis in the United States: National trends, variances, prognosis, and management. Laryngoscope 2010;120 (6):1256-62.

4) Chu HS, Jung EJ, Jung JY, Woo JS, Hwang SJ, Lee HM. Acute epiglottitis in adults: a review of 85 patients. Korean J OtorhinolaryngolHead Neck Surg 2004;47(6):558-61.

5) Chan KO, Pang YT, Tan KK. Acute epiglottitis in the tropics: Is It an adult disease? J Laryngol Otol 2001;115(9):715-8.

6) Shah RK, Nussenbaum B, Kienstra M, Glenn M, Brereton J, Patel $\mathrm{MM}$, et al. Wrong-site sinus surgery in otolaryngology. Otolaryngol Head Neck Surg 2010;143(1):37-41. 
7) Ng HL, Sin LM, Li MF, Que TL, Anandaciva S. Acute epiglottitis in adults: a retrospective review of 106 patients in Hong Kong. Emerg Med J 2008;25(5):253-5.

8) Nakamura H, Tanaka H, Matsuda A, Fukushima E, Hasegawa M. Acute epiglottitis: a review of 80 patients. J Laryngol Otol 2001;115 (1):31-4.

9) Kass EG, McFadden EA, Jacobson S, Toohill RJ. Acute epiglottitis in the adult: experience with a seasonal presentation. Laryngoscope 1993;103(8):841-4.

10) Damm M, Eckel HE, Jungehülsing M, Roth B. Management of acute inflammatory childhood stridor. Otolaryngol Head Neck Surg 1999; 121(5):633-8

11) Smith MM, Mukherji SK, Thompson JE, Castillo M. CT in adults supraglottis. AJNR Am J Neuroradiol 1996;17(7):1355-8.

12) Tintinalli JE, Stephan Stapczynski J, John Ma O, Cline DM, Cydulka RK, Meckler GD. Emergency medicine. A comprehensive study guide. 7th ed. New York: McGraw-Hill;2011. p.191.
13) Gilbert DN, Moellering RC, Eliopoulos GM, Chambers HF, Saag MS. The Sanford guide to antimicrobial therapy. 40th ed. Sperryville: Antimicrobial Therapy Inc;2010. p.65.

14) Ward MA. Emergency department management of acute respiratory infections. Semin Respir Infect 2002;17(1):65-71.

15) Glynn F, Fenton JE. Diagnosis and management of supraglottis (epiglottitis). Curr Infect Dis Rep 2008;10(3):200-4.

16) Frantz TD, Rasgon BM, Quesenberry CP Jr. Acute epiglottitis in adults. Analysis of 129 cases. JAMA 1994;272(17):1358-60.

17) Hébert PC, Ducic Y, Boisvert D, Lamothe A. Adult epiglottitis in a Canadian setting. Laryngoscope 1998;108(1 Pt 1):64-9.

18) MayoSmith MF, Hirsch PJ, Wodzinski SF, Schiffman FJ. Acute epiglottitis in adults. An eight-year experience in the state of Rhode Island. N Engl J Med 1986;314(18):1133-9.

19) Guldfred LA, Lyhne D, Becker BC. Acute epiglottitis: epidemiology, clinical presentation, management and outcome. J Laryngol Otol 2008;122(8):818-23. 